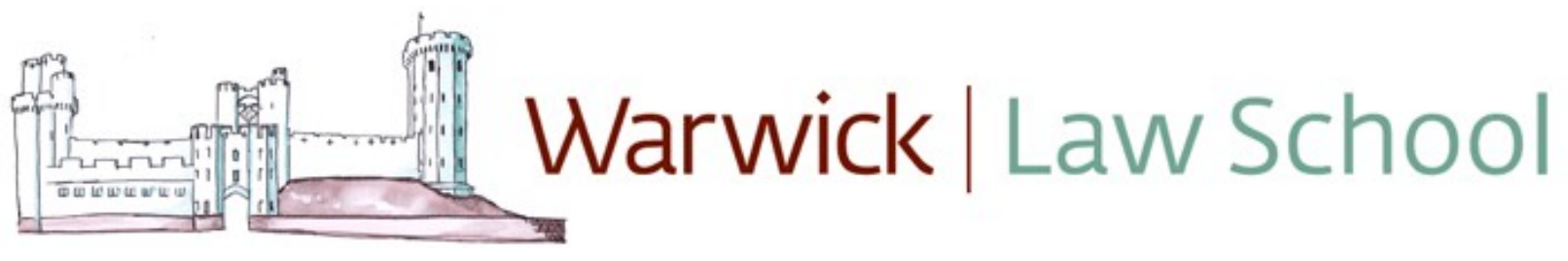

\title{
University of Warwick School of Law
}

Legal Studies Research Paper No. 2013-18

Testing Liberal Norms: The Public Policy and Public Security Derogations and the Cracks in European Union Citizenship

Theodora Kostakopoulou

University of Warwick - School of Law

Nuno Ferreira

University of Liverpool 


\section{Introduction ${ }^{1}$}

Crises in liberalism are not merely triggered by exogenous factors, such as international terrorism, wars, global economic downturns and natural disasters. They can also emerge endogenously when basic principles underpinning liberalism come adrift and, like soap bubbles, fluctuate and then burst when they come into contact with a new idea or a harsh reality. One such harsh reality is insecurity of residence and the principles of liberalism that it challenges are freedom from state coercion, human emancipation from unnecessary restrictions and the equal treatment of all individuals irrespective of their place of birth and nationality.

We take it as given that citizens have the right to enter and reside freely and unconditionally in the country they call 'their own'. ${ }^{2}$ Migrants, on the other hand, can never take security of residence for granted. Notwithstanding the length of their residence in the territory of the host state and their immersion into a multifarious web of socioeconomic relations, their future is always precarious; they can be ordered to leave the country if state authorities view their presence as not 'conducive to the public good' and a threat to public policy or national security. In the past, misfortune or injustice or both could easily cause their dislocation and departure. Economic recessions have also been used as either reasons or pretexts for the expulsion of migrant workers. Additionally, public policy, public morality and national security have been

\footnotetext{
${ }^{1}$ Research for this article was carried out under the Jean Monnet Project on 'The Reconceptualisation of European Union Citizenship' (2010-12) funded by the European Commission. The authors are grateful to the Commission for the financial support. Earlier versions, and parts of it, have been delivered by Dora Kostakopoulou at the following meetings: Sixth Pan-European Conference on EU Politics, ECPR, Tampere, Finland, 13-15 September 2012; UACES 42nd Annual conference, Old Borders, New Frontiers, University of Passau, 3-5 September 2012; Conference on 'The Human Face of the European Union: Humane Enough?' Manchester, University of Manchester, 20 July 2012; the 19th International Conference of Europeanists, Boston, MA, 22-24 March 2012; 2nd Jean Monnet Workshop on the Reconceptualisation of EU Citizenship, Universidad Pontificia Comillas, Madrid, 7-8 October 2011; European Union Citizenship: Enduring Patterns and Evolving Norms, EUSA 12th Biennial International Conference, Boston MA, 3 - 5 March 2011. We would like to thank all the participants in the above mentioned events for questions and comments.

${ }^{2}$ See Article 3 of the Fourth Protocol to the 1950 European Convention on Human Rights (ECHR).
} 
interpreted widely by states in order to force the exit of migrant workers. Trivial incidents find their way into justifications for exclusion and it is often the case that norms and standards are not always administered correctly by lower courts and administrative authorities.

Fortunately, those migrants who are beneficiaries of European Union law enjoy considerable protection against experiences of injustice and illegitimate harm inflicted by state authorities because the public policy, public security and public health derogations from the Treaty's provisions on the free movement of persons have to be interpreted strictly and there is a demand for the justification of state actions to be in line with the standards prescribed by European Union law.

But while the traditional discretion enjoyed by states in ordering non-nationals to leave their territory has been curtailed by European Union law, and even states which are not members of the European Union would not 'eject at their pleasure' non-national residents who have not committed any offence, the system of protection afforded to offending European Union citizens, nevertheless, contains a number of cracks. These will have to be corrected in the near future not only because they lead to policy incoherence and gaps in rights protection, but also because they threaten to transform European Union citizenship from a fundamental status into a thin overlay which, under pressure from national executive power, loses its effect and significance.

Investigating those cracks and how they could be corrected is the main focus of the present article. True, it may be objected from the outset that no sympathy should be given to offending EU citizens residing in the territory of Member States whose rules and laws they fail to respect. For by failing to respect the requirements of hospitality, they, essentially, forfeit their right to receive such hospitality and to deserve any special protection. Although such a view is certainly understandable, most fair minded individuals would find it troubling if the penalty imposed for offending conduct does not meet the requirements of proportionality and causes irreparable and, in the opinion of some, illegitimate, harm to human beings. 
Indeed, it is one thing to accept the penalty accompanying a transgression and quite another to be placed outside the society's circle of membership. Being stripped of membership status and being rendered 'homeless' shatters lives, destroys personal identities and tears apart social and family relations. After all, 'home' is not only the place where we feel safe, our lives are woven and entangled with the lives of others and where our identities are manifested and shaped. In addition to its spatial dimension, 'home' also has another temporal dimension in the sense that we cannot imagine our life and contemplate future life choices without it. Home settles people in the sense that it allows them to make commitments, imagine and plan their future. In this respect, 'homelessness', that is, being ordered to leave a country in which you have made your home, not only makes us feel abandoned and hurt, it also makes us feel futureless. Without security of residence, personal autonomy, that is, the right to lead a meaningful life and to make life choices, is meaningless. Because deportation not only makes EU citizens' lives, expectations and future less worthy of respect, but also negates them completely, the effect of the public policy and public security derogations in Directive 2004/38 on Union citizenship itself must be seriously examined.

The subsequent discussion is structured as follows. In section 2 we examine the 'old' and 'new' interpretative frameworks relating to public policy and public security derogations and examine the shortcomings in the judgments in the first cases on Article 28(3) of Directive 2004/38 that have reached the Court of Justice of the EU (CJEU). In section 3 we consider whether EU migration and external relations laws could shed light on the conceptual ambiguity surrounding the terms public security and public policy which underpin deportation decisions, while in section 4 we extend our search for a solution to the Court's interpretation of these terms across the four fundamental freedoms. We argue, in section 5, that international migration law, and not European Union law, could provide useful pointers and inspiration for the reform of law and policy in this area and in the concluding section we discuss, and defend, our proposals for institutional reform. 


\section{The public policy and public security derogations: Past and present}

The public security, public policy and public health derogations from free movement have been marked by a disjunction between governmental interests and sovereign power and EU regulation. Member States have been keen to maintain the vestiges of their sovereignty in the sphere of migration law. Accordingly, they have preserved the power to restrict the free movement rights of Union citizens and their family members on public security, public policy and public health grounds (Article 45(3) TFEU). But these grounds must be strictly interpreted and comply with the principle of proportionality, ${ }^{3}$ cannot be invoked in order to serve economic ends even in times of recession, and cannot be imposed automatically. ${ }^{4}$ Instead, they have to be based exclusively on the personal conduct of the individual concerned. The Member States are obligated to verify that a Union citizen's personal conduct poses 'a genuine and sufficiently serious threat to the requirements of public policy affecting one of the fundamental interests of society' ${ }^{5}$ This is not merely confined to entry; it also applies to restrictions on the right of exit imposed by the Member State of origin on one of its nationals. In Jipa, a reverse discrimination case since the applicant requested his state of origin to lift a restriction on his right to cross-border movement (Article 38 of Romanian Law 248/2005) in order to travel to Belgium which had repatriated him owing to his irregular residence there, the Court ruled that in the absence of a genuine threat to public policy or public security the Member State of origin cannot restrict an EU national's right

\footnotetext{
${ }^{3}$ Case C-100/01 Ministre de l'Interieur v Aitor Oteiza Olazabal, Judgment of the Court of 26 November 2002; Joined Cases C-482/01 and C-493/01 Orfanopoulos and Oliveri v Land Baden-Wurttemberg [2004] ECR I-5257; Case C-430/10 Hristo Gaydarov v Direktor na Glavan direktsia 'Ohranitelna politsia' pri Ministerstvo na vatreshnite raboti, Judgment of the Court of 17 November 2011, paragraph 32.

${ }^{4}$ See the Opinion of AG Mazak in Case C-33/07 Gheorghe Jipa, delivered on 14 February 2008, point 23.

${ }^{5}$ Case 30/77 R v Bouchereau [1977] ECR 1999.
} 
of exit. ${ }^{6}$ In Gaydarov, the Court ruled that 'the genuine, present and sufficiently serious threat to the requirements of public policy' test, observance of the principle of proportionality and the subject of the restrictive measure to effective judicial review can justify the restriction of the right of a Member State national to exercise the fundamental rights of entry and residence. The same assessment must take place with respect to third country national spouses of EU nationals who have been the subject of alerts entered in the Schengen Information System. The CJEU has stated that both the Member State issuing an alert and the Member State that consults the Schengen Information System must first establish that the presence of a person constitutes a genuine, present and sufficiently serious threat affecting one of the fundamental interests of society. ${ }^{7}$

The Court's clear preference for a rights-based approach to the interpretation of the Treaty's derogations from free movement in the internal market shields individuals from the discretionary power of states. As protected persons, their interests take priority over the interests of states. From this it follows that public policy or security risks must be clearly linked to particular persons before any action is taken by national authorities against an EU citizen. By requiring concreteness, as opposed to abstract interpretations of threats or risks, and contextualism, that is, the identification of real and specific harms caused by individuals' actions as opposed to abstract harms and exaggerated risks flowing from authorities' perceptions about certain (unwanted) individuals and their actions, EU nationals and their families have been shielded from utilitarian calculations and arbitrary state practices. Accordingly, a Member State cannot order the expulsion of a Union citizen as a deterrent or a general preventive action. ${ }^{8}$ Nor can exclusion or expulsion decisions be justified on the basis of governmental policy agendas, such as, for example, tackling pornography or organized crime. This also rules out the application

\footnotetext{
${ }^{6}$ Case C-33/07 Gheorghe Jipa, Judgment of the Court of 10 July 2008. Romania had placed this restriction following a Readmission agreement it had signed with Belgium before its accession to the EU.

${ }^{7}$ Case C-503/03 Commission v Kingdom of Spain, Judgment of the Court of 31 January 2006.

${ }^{8}$ Case 67/74 Bonsignore [1975] ECR 297, paragraph 6, and Case 36/75 Rutili [1975] ECR 1219, paragraph 29.
} 
of pre-emption or the precautionary principle which became salient in counter-terrorist law and policy post $9 / 11$.

Additionally, previous criminal convictions will not in themselves constitute grounds for imposing limitations on cross-border movement. ${ }^{9}$ As Article 27(2) of Council Directive 2004/38 states, "justifications that are isolated from the particulars of the case or that rely on considerations of general prevention shall not be accepted'. According to Advocate General Mazák, 'it follows from the ruling of the Court in Commission v Spain that a Member State, when limiting the rights granted to Union citizens pursuant to Article 18(1) EC [21 TFEU], cannot rely on general non-specific assertions made, in relation to the conduct of a Union citizen, by another Member State. A Member State when limiting the fundamental freedoms of Union citizens must itself verify and confirm whether the exercise of those freedoms poses a genuine and sufficiently serious threat to the requirements of public policy affecting one of the fundamental interests of society' (footnotes omitted). ${ }^{10}$ True, there is no isomorphism in the definition of public policy across the EU - public policy and public security remain 'national concepts', that is, they are defined on the basis of national laws and traditions. However, the Court has clearly stated for more than three decades that the Member States' discretion in this area is circumscribed by EU law. ${ }^{11}$

Although the strict interpretation of the public policy derogations furnished by secondary legislation (Directive 64/221 initially and Directive 2004/38 from 30 April 2006) and the Court's jurisprudence have circumscribed the Member States' discretionary power, they nevertheless continue to deport Union citizens on the basis of enforceable criminal convictions. In Calfa automatic expulsion for life following a criminal conviction, without consideration of the personal conduct of the offender or the danger (s)he represented, on the basis of public policy, was seen to contravene Treaty provisions (formerly Article 49 EC) and Directive 64/221 (now

\footnotetext{
${ }^{9}$ Article 27(2) of Directive 2004/38; Case C-348/96 Calfa [1999] ECR I-11, paragraphs 22 to 24.

${ }^{10}$ See Opinion in Case C-33/07 Gheorghe Jipa, $\mathrm{n} 7$ above, point 43.

${ }^{11}$ Case 41/74 van Duyn [1974] ECR 1337.
} 
Directive 2004/38). ${ }^{12}$ And Advocate General Stix-Hackl has stated in Commission v Germany that 'the German practice of automatic deportation, without regard for personal circumstances, justified on the ground of its deterrent effect on other foreigners and in breach of the fundamental right to family life breaches Community law'. ${ }^{13}$ In Huber the Court took issue with the German Central Register of Foreign Nationals and ruled that the prohibition of discrimination on the ground of nationality laid down in Article 18 TFEU precludes the establishment of a system specifically for Union citizens for processing personal data for the purpose of fighting crime while no such similar system exists with respect to nationals of that Member State. But it reached the opposite conclusion with respect to the use of a central register for foreign nationals for the purpose of regulating their residential status. ${ }^{14}$

The Citizenship Directive has enhanced security of residence for Union citizens and their family members. National authorities contemplating the taking of an expulsion decision must take into account a complex array of factors, such as the length of an individual's residence on the national territory since this reflects the strength of his/her link with the host Member State, his/her age, state of health, family and economic situation, social and cultural integration into the host Member State and the extent of his/her links with the country of origin. ${ }^{15}$ Frequent and long absences from the territory (not exceeding two consecutive years) would presumably indicate the existence of a weaker link with the host Member State. In contrast, long and uninterrupted residence manifests a greater degree of integration in the host Member State thereby necessitating a greater level of protection against expulsion; in such cases, 'uprooting' would result in serious

\footnotetext{
${ }^{12}$ Case C-348/96 Calfa $\mathrm{n} 8$ above.

${ }^{13}$ See the Advocate General's Opinion in Case C-441/02 Commission v Federal Republic of Germany, 2 June 2005; [2006] ECR I-3449.

${ }^{14}$ Case C-524/06 Heinz Huber v Bundesrepublik Deutschland, Judgment of the Court of 16 December 2008.

${ }^{15}$ Article 28(1) of Directive 2004/38.
} 
and multiple harms for individuals and their families. ${ }^{16}$ In the case of a Union citizen 'who has lawfully spent most or even all of his childhood and youth in the host Member State, very good reasons would have to be put forward to justify the expulsion measure' ${ }^{17}$

The Directive also stipulates that permanent residents can be ordered to leave only on ‘serious grounds of public policy or public security' (Article 28(2)), and that Union citizens resident for the previous ten years and minors may not be ordered to leave the territory of a Member State, except 'on imperative grounds of public security' (Article 28(3)). ${ }^{18}$ In addition, according to Article 33 of Directive 2004/38, an expulsion order cannot be issued by the host Member State as a penalty or legal consequence of a custodial penalty unless the general requirements pertaining to the application of restrictions on entry and residence apply (Articles 27-29) and, if it is issued, it should be subject to assessment after two years (Article 33). In cases of interrupted residence in the ten-year period required for the activation of the high degree of protection against expulsion under Article 28(3), national authorities can take into consideration the duration of each absence from the national territory, the frequency and cumulative duration of those absences, the reasons for the absences and any evidence that appears to suggest that the individual concerned intended to transfer the hub of his/her life and activities to the Member State of origin or another Member State. ${ }^{19}$

The distinction between the high level of protection provided by the requirement of 'serious grounds of public policy and public security' under Article 28(2) and the higher level of protection entailed by the phrase 'imperative grounds of public security' under Article 28(3) as well as the meaning of the latter phrase have arisen in two recent cases before the Court; namely, Case C-348/09 Pietro Infusino v Oberburgermeisterin der Stadt Remscheid lodged on 31 August

\footnotetext{
${ }^{16}$ See recital 24 of the Preamble to Directive 2004/38. See also points 44, 45 and 115-19 of AG Bot's Opinion in Case C-145/09 Land Baden-Wurttemberg v Panagiotis Tsakouridis, which was delivered on 8 June 2010.

${ }^{17}$ Paragraph 53 of the Judgment of the Court in Case C-145/09 Land Baden-Wurttemberg v Panagiotis Tsakouridis, delivered on 23 November 2010.

${ }_{18}^{18}$ Article 28(3) of Directive 2004/38.

${ }^{19}$ See paragraphs 32-34 of the Judgment of the Court in Tsakouridis $\mathrm{n} 16$ above.
} 
2009 and the Tsakouridis case noted above. In both cases, the referring courts sought guidance as to whether the absence of any reference to public policy matters in Article 28(3) implies that this provision is confined to threats to internal and external security of the state which put at risk its continued co-existence, its institutions and important public services, the survival of the population, foreign relations and the peaceful co-existence of nations. A literal interpretation of Article 28(3) appears to lend credence to a restrictionist approach, that is, to its confinement to very serious conduct which undermines state security and threatens to jeopardize its functions and the survival of the population. But in Tsakouridis, the Court made it clear that the term 'imperative grounds of public security' does not necessarily exclude domestic criminal law matters and that the fight against crime in connection with dealing in narcotics as part of an organized group, which undoubtedly falls within the ambit of Article 28(2), is capable of being covered by Article 28(3). ${ }^{20}$

This ruling essentially makes the distinction between the second and third paragraphs of Article 28 inexact, notwithstanding the existence of close conceptual links between internal security and public policy. Underlying the Court's ruling appears to be the belief that the differentia specifica between Articles 28(2) and 28(3) is not the so much the nature of the threat after all, the meanings of public policy and security ${ }^{21}$ cannot be clearly demarcated and, having varied meanings in the various Member States, remain national law concepts, albeit circumscribed by EU law. Instead, attention should be given to the 'exceptional circumstances' surrounding the offending conduct and the 'high degree of seriousness' it reflects - elements that

\footnotetext{
${ }^{20}$ Ibid.

${ }^{21}$ According to AG Bot, the concept of public policy includes, inter alia, the prevention of urban violence, the prevention of the sale of stolen cars, protection of the right to mint coinage and respect for human dignity; point 63 of AG Bot's Opinion in Tsakouridis. However, he went on to state that in most of the cases, the Court has not made a distinction between the two concepts and used Olazabal to substantiate this point. See also paragraphs $43-45$ of the Court's decision.
} 
are captured by the adjective 'imperative'. ${ }^{22}$ This could be termed the 'counter-restrictionist' view.

Accordingly, Tsakouridis gives the impression that national authorities contemplating expulsion decisions need not be concerned about the object of the threat, that is whether the survival of the state (and its institutions) is threatened. Nor is it the case that what triggers the application of Article 28(3) is the 'specialness' of the public security threat. Imperative grounds of public security do not presuppose the existence of special security threats. Instead, the circumstances of the threat must be exceptional thereby justifying the exceptionality of the deportation of very long-term residents and minors; the threat must exhibit a high degree of seriousness which is not found in ordinary criminal activities. ${ }^{23}$ It would be up to the Member State to furnish coherent arguments highlighting the extraordinary circumstances surrounding the threat, while EU citizens challenging expulsion decisions would have to produce counterbalancing evidence that the threat they pose does not go beyond normal security procedures. In other words, the Court's contribution to the definition of the term 'imperative grounds of public security' is to shift the focal point of an examination from the type of the security threat itself to the security constellation accompanying the offending conduct. For it is that security constellation which will move a conduct which could be caught by either public policy or public security into the exceptional area of public security.

This shift has been confirmed by the Grand Chamber's judgment in Pietro Infusino mentioned above. ${ }^{24}$ Infusino, an Italian national, who had lived in Germany since 1987, was sentenced to seven years' imprisonment in 2006 for the sexual assault, sexual coercion and rape

\footnotetext{
${ }^{22}$ Paragraphs 40 and 41 of the Court's Judgment in Tsakouridis $\mathrm{n} 16$ above.

${ }^{23}$ Of course, the test of proportionality must always be carried out and national authorities contemplating the taking of an expulsion decision must consider other factors, such as the length of residence in the host Member State, the protection of the right to privacy and family life enshrined in the Charter of Fundamental Rights (Article 7) and the ECHR (Article 8) and must not prejudice the offender's social rehabilitation in the state in which he/she has become genuinely integrated.

${ }^{24}$ Case C-348/09, Pietro Infusino v Oberburgermeisterin der Stadt Remscheid, Judgment of the Court of 22 May 2012.
} 
of his former partner's daughter who was eight years old when the offences were committed. He is due to be released in July 2013, and in May 2008 a deportation order was issued which Infusino subsequently challenged. The Higher Administrative Court for the Land North RhineWestphalia, which heard the case on appeal, sought the CJEU's guidance on the application of Article 28(3) of the Citizenship Directive by enquiring as to whether, besides dealing in narcotics as part of an organized group, other extremely serious criminal offences fall within its scope. The Court drew upon Article 83(1) TFEU which pronounces the sexual exploitation of children as a serious crime with a cross-border dimension in which the EU may intervene and Directive 2011/93 on combating the sexual abuse and sexual exploitation of children and child pornography, ${ }^{25}$ in order to make an unprecedented widening of the public security derogation, since it can now encompass all criminal offences which 'might pose a direct threat to the calm and physical security of the population' as long as 'the manner in which such offences were committed discloses particularly serious characteristics, which is a matter for the referring court to determine'. ${ }^{26}$ The security constellation surrounding the offence is thus the paramount consideration - and not the type of offence. And given that in principle all forms of criminality can be seen to pose a direct threat to the calm and physical security of the population, Article 28(3) becomes a gradation of Article 28(2) of Directive 2004/38. Particularly serious crime can thus activate the application of Article 28(3). One cannot but wonder about the reasons that led the Court to instigate a definitional isomorphism between public security and public policy (and public order) by infusing the former with an 'everyday' dimension relating to the preservation of the 'calm and physical security of the population'. While the 'everydayness' or 'normalization' of the public security derogation will please Member States which remain free to categorize conduct as contrary to public security 'according to the particular values of their legal order', ${ }^{27}$ it is deeply

\footnotetext{
${ }^{25}$ OJ 2011 L 335.

${ }^{26}$ Paragraphs 28-29 and 33 of the Judgment, n 23 above. Pietro Infusino had threatened and isolated his victim for a number of years.

${ }^{27}$ Ibid., paragraph 29.
} 
problematic and worrying from the point of view of EU law. The phrase 'threat to the calm and physical security of the population' constitutes an interpretational innovation (Tsakouridis referred to the economic and social danger for society) which undermines the rationale of the Citizenship Directive and its objectives of promoting security of residence for long-term resident EU citizens and enhancing their citizenship status. ${ }^{28}$ Similarly, the reference to the referring court's assessment of conduct leading to expulsion in the light of 'the particular values of the legal order of the Member State' (paragraph 29) is so ambiguous that it is bound to lead to legal uncertainty and the unequal treatment of Union citizens throughout the European Union. The Grand Chamber's deference to the Member States' 'interpretational freedom' may be attuned to the present rise in Euro-scepticism in several countries, but it is certainly at odds with its traditional attestation of the strict interpretation of the derogations.

We have reservations as to whether the shift from security threat to security constellation reflects the intentions of the European legislature. If this were the case, Article 28(3) would read 'imperative grounds of public policy or public security' thereby making the difference between $28(2)$ and 28(3) an issue of scale, that is, a matter of the degree of the seriousness of the threat. In addition, in its Guidance for better transposition and application of Directive 2004/38/EC on the right of citizens of the Union and their family members to move and reside freely within the

\footnotetext{
${ }^{28}$ Interestingly, AG Bot reached a totally different conclusion by applying the same consideration: Opinion delivered on 6 March 2012. In AG Bot's opinion, Infusino's conduct did not reach a level of intensity that might directly threaten the calm and physical security of the population as a whole or a large part of it; he was not a threat to the security of the citizens of the Union by being a sexual predator and thus his conduct was not covered by the concept of 'imperative grounds of public security' (paragraphs 44-47). However, in a problematic way, the AG did import a very contestable and state-derived argument about the integration of Union citizens in the host Member State which made the Citizenship Directive subordinate to Member States' views of integration of third country nationals, thereby ignoring the fact that the only conception of integration characterizing free movement of persons is one based on rights, non-discrimination on the ground of nationality and equal opportunities. Permanent residence in the meaning of the Directive 2004/34 is not predicated on a 'test of integration', as the Netherlands Government submitted, which can be rebutted. On the divergent notions of integration with respect to internal mobility and external migration, see D. Kostakopoulou, S. Carrera and M. Jesse, 'Doing and Deserving: Competing Frames of Integration in the European Union', in Carrera et al. (eds.), Illiberal, Liberal States: Immigration, Citizenship and Integration in the EU (Ashgate, 2009) and D. Kostakopoulou, 'The Area of Freedom, Security and Justice and the Political Morality of Migration and Integration', in H. Lindahl (ed.), A Right to Inclusion and Exclusion? Normative Fault Lines of the EU's Area of Freedom, Security and Justice (Oxford: Hart, 2009), 185-207.
} 
territory of the Member States, the Commission has explicitly stated that it is crucial that Member States define clearly the protected interests of society, and make a clear distinction between public policy and public security. The latter cannot be extended to measures that should be covered by the former. Public security is generally interpreted to cover both internal and external security along the lines of preserving the integrity of the territory of a Member State and its institutions. Public policy is generally interpreted along the lines of preventing disturbance of social order. ${ }^{29}$ Having said this, however, one cannot preclude a future amendment of Article 28(3) so as to include a reference to 'public policy'. Alternatively, the Court could define the types of threats ${ }^{30}$ that could be caught by it in a clear and comprehensive, albeit non-exhaustive, manner in its subsequent jurisprudence.

Notwithstanding the Court's supervision of Member States' compliance with EU law and the increasing weight and relevance of European Union citizenship, it may be argued that the continuation of the practice of deportation on the grounds of security and public policy, particularly in the cases of long-term resident EU citizens and minors, undermines the principle of equal treatment irrespective of nationality, a principle fostered by Union citizenship. To put it differently, is it perhaps time to consider seriously the abolition of Article 28(3)? Given the importance of the fundamental status of EU citizenship and the fact that more than ten years residence would be the necessary qualifying period for naturalization in most Member States, does it make sense to preserve states' power to break the bond between an EU citizen and the host community by ordering his/her dislocation? ${ }^{31}$ After all, it can be plausibly argued that the criminal justice system offers ample scope to punish the unlawful conduct of permanent EU

\footnotetext{
${ }^{29}$ Communication from the Commission to the European Parliament and the Council, $\operatorname{COM}(2009) 313$ final, Brussels, 2 July 2009, page 10.

${ }^{30}$ These could include armed struggle, terrorism and cyber-terrorism, serious organized crime and cybercrime. An interesting question that arises here is whether a Member State could view an EU citizen's conduct resembling Julian Assange's Wikileaks disclosures as conduct justifying expulsion from the host Member State on 'imperative grounds of public security' even after a 20 -year residence there.

${ }^{31}$ Belgium provides absolute protection from withdrawal (and non-renewal) of settled migrants' resident permits since the status of settlement is deemed to be permanent. Additionally, residents born in Belgium and those who have lived in Belgium from the age of 12 onwards cannot be deported.
} 
citizens in the same manner as that of nationals, without transforming the former into 'dangerous outsiders' who 'must be expelled from the national body'. ${ }^{32}$ In other words, the contingency of nationality need not be a critical consideration if an EU citizen has a very solid link with the host state owing to birth on its territory, childhood and schooling, age and family connections or longterm residence exceeding ten years. Such an approach would make the restrictionist/counterrestrictionist dualism mentioned above obsolete.

As present, it remains the case that, as far as security of residence is concerned, Union citizenship appears to be a lesser status than that of national citizenship. Essentially, it approximates to third country national long-term residence status. As Jesse has observed in another context, "strong protection from forced removal or revocation of statuses is a signal that a society accepts individuals as members. Full members of society, i.e., nationals, are not under any threat to be expelled. The threat of removal is thus always a reminder of differentiation in status and membership. ${ }^{33}$ This stratified notion of membership and the degrading of EU citizenship give rise to an additional internal contradiction: while the establishment and development of EU citizenship have demonstrated that community belonging does not have to be based on organicnational qualities, cultural commonalities or individuals' conformity to national values, but can be built on de facto associative relations and connections brought about through residence in the host community and de jure equal membership as far as possible,${ }^{34}$ the continued deportation of longterm resident Union citizens effectively makes nationality the ultimate determinant of belonging. ${ }^{35}$ The legal contours of Union citizenship thus become fractured and the European

\footnotetext{
${ }^{32}$ Compare the emphasis on connections with the host society of an EU citizen who is a permanent resident in relation to the execution of a European arrest warrant given by the Grand Chamber in Case C-123/08, Dominic Wolzenburg, Judgment of 6 October 2009, paragraphs 64-70.

${ }^{33}$ M. Jesse, The Civic Citizens of Europe: Legal Realities for Immigrants in Europe and the Legal Potential for their Integration, PhD Dissertation, EUI: Florence, October 2010, at p. 259.

${ }^{34}$ D. Kostakopoulou, 'European Union Citizenship: Writing the Future', European Law Journal, Vol. 13(5), 2007, 623-646.

${ }^{35}$ By so doing, it facilitates the stigmatization of EU citizens and the possible erosion of their special, citizen status in the host Member States by official discourses on the deportation of foreign criminals. Such anti-migrant and xenophobic discourses have featured in the media in the UK, Italy and the Netherlands recently.
} 
Union becomes transformed from a community of law into a community of state-defined national memberships.

\section{Looking for guidance inside European Union law}

\subsection{EU migration and external relations laws}

Having identified the analytical as well as empirical shortcomings entailed by Article 28 of Directive 2004/38, the crucial question that needs to be addressed now is whether EU migration law contains any resources that could be utilized in the process of enhancing the security of residence of Union citizens in the host Member State. Directive 2003/109, the so-called long-term residence directive, embraces the principle that domicile generates an entitlement to increasing security of residence. ${ }^{36}$ Indeed, Recital 16 refers to the 'reinforced' protection against expulsion that long-term resident third country nationals (TCNs) ought to enjoy. Guided by, albeit not perfectly reflecting, the Tampere mandate of providing a set of rights which are 'as near as possible' to those enjoyed by citizens of the European Union, the Directive embeds the Court's case law concerning Article 39(3) EC (now Article 45(3) TFEU) and Directive 64/221 into Article 12: expulsion can take place solely when a TCN constitutes an actual and sufficiently serious threat to public policy or public security. Public health, notably, is excluded as a ground. In addition, Article 12(2) repeats the provision of the former Directive 64/221 and its successor Directive 2004/38 establishing that economic considerations are not permitted grounds for making expulsion decisions, while Article 12(3) incorporates the considerations derived from the jurisprudence of the European Court of Human Rights (ECtHR), in particular with respect to

\footnotetext{
${ }^{36}$ Directive 2003/109/EC concerning the status of third country nationals who are long-term residents, OJ L 16/44, 23 January 2004.
} 
Article 8 ECHR (respect for private and family life). However, the standard requirement that previous criminal convictions do not automatically constitute grounds for exclusion, entailed by Article 3(2) of Directive 64/221 as well as by Article 27(2) of Directive 2004/38, was omitted in the final version of the long-term residence Directive. Similarly, the standard EU law requirement that one's personal conduct must represent a genuine, present and sufficiently serious threat affecting one of the fundamental interests of society, featured in Article 27(2) of Directive 2004/38 and discussed extensively in the previous section, is not mentioned.

True, the above mentioned omissions should not be regarded as fundamental flaws since the Court is bound to apply its existing case law by analogy should a case on these matters reach it. After all, the Commission's commentary on the Articles of the Directive clearly stated that a person's personal conduct is the decisive criterion justifying an expulsion decision and that the proportionality test has to be met. What, in our opinion, is an important fault line of the long-term residence Directive, however, is its silence concerning the enhanced level of protection that longstanding residents (for more than ten years) and minors ought to enjoy by analogy with the provisions of the Citizenship Directive.

Statal objections and concerns precluded long-term residents' equalization in this domain. ${ }^{37}$ In Nural Ziebell Advocate General Bot defended the distinction between the increased level of protection afforded to longstanding resident EU citizens in the territory of a host Member State under Article 28(1) of Directive 2004/38, on the one hand, and the lesser protection afforded to TCN residents, including those of Turkish nationality under Article 14(1) of Council Decision $1 / 80$, on the other, on the basis of their differing legal status. ${ }^{38}$ And with respect to residence in other Member States, a long-term resident TCN may not be allowed to reside if 'the person concerned constitutes a threat to public policy or public security'. However, as Article

${ }^{37}$ On this see S. Peers, 'Implementing Equality? The Directive on Long-Term Resident Third Country National', European Law Review, Vol. 29 (4), 2004, pp. 437-460, at 452; Diego Acosta Arcarazo, The Long-Term Residence Status as a Subsidiary Form of EU Citizenship (Leiden: Brill, 2011), chapter 5.

${ }^{38}$ Case C-371/08 Nural Ziebell v Land Baden-Wurttemberg, Opinion of AG Bot delivered on 14 April 2011, points 55, 62 et seq. 
17(1) paragraph 2 states, 'when taking the relevant decision, the Member State shall consider the severity or type of offence against public policy or public security committed by the long-term resident or his/her family member(s), or the danger that emanates from the person concerned'. And as Article 17(2) of Directive 2003/109 reiterates, such a decision must not be based on economic considerations.

The Blue Card Directive, too, includes public policy, public security or public health as grounds for withdrawing or refusing to renew an EU Blue Card. ${ }^{39}$ Of course, officials' decisions in such cases should be open to legal challenge in accordance with the relevant national law (Article 11(3)). The requirement that individuals should not be considered to pose a threat to public policy, public security or public health is also found in Articles 7(1) and 13(2) of the Researchers' Directive ${ }^{40}$ as well as in Articles 6(1)(d) and 16(2) of the Pupils' Directive. ${ }^{41}$ The Family Reunification Directive's preambulary references to public policy or public security, on the other hand, are more explicit as regards the meaning of public policy. The Directive states that in refusing to grant family reunification on the duly justified grounds, the notion of public policy may cover a conviction for committing a serious crime (Article 6) and that the notions of public policy and public security also cover cases where a third country national belongs to an association which supports terrorism, supports such an association or has extremist aspirations (Recital 14). ${ }^{42}$ Having said this, however, it should be noted here that the Family Reunification Directive is also attuned to the ECtHR case law: ${ }^{43}$ Article 6(2) paragraph 2 states that "when taking the relevant decision, the Member State shall consider, besides Article 17, the severity or type of offence against public policy or public security committed by the family member, or the

\footnotetext{
${ }^{39}$ Article 9(3)(a) of Directive 2009/50/EC of 25 May 2009 on the conditions of entry and residence of third country nationals for the purpose of highly qualified employment, OJ L 155/17, 18 June 2009.

${ }^{40}$ Council Directive 2005/71 EC of 12 October 2005 on a specific procedure for admitting third country nationals for the purposes of scientific research, OJ L 289/15, 3 November 2005.

${ }^{41}$ Council Directive 2004/114/EC on the conditions of admission of third country nationals for the purposes of studies, pupil exchange, unremunerated training or voluntary service, OJ L 375/12, 23 December 2004.

${ }^{42}$ Council Directive 2003/86/EC of 22 September 2003 on the right to family reunification, OJ L 251/12, 3 October 2003.

${ }^{43}$ Moustaquim v Belgium, 18.2.1991 Series A no 193 and Beldjoudi v France, 26.3.1992.
} 
dangers that are emanating from such person'. And Article 17 of the Directive requires the Member States to take into account three criteria, namely, family ties, the duration of residence in the host Member State and the existence of links with the country of origin; 'Member States shall take due account of the nature and solidity of the person's family relationships and the duration of his residence in the Member State and of the existence of family, cultural and social ties with his/her country of origin where they reject an application, withdraw or refuse to renew a residence permit or decide to order the removal of the sponsor or members of his family'. Evidently, this list is shorter than the list of considerations applying to expulsion decisions taken against EU citizens - age, state of health and social and cultural integration in the host Member State are not mentioned. ${ }^{44}$ Accordingly, in the light of the foregoing discussion it may be concluded that EU migration law does not contain any resources which could be utilized in closing the protection gaps identified in Chapter VI (public policy, public security or public health restrictions) of the Citizenship Directive. It is destined to approximate, rather than to supplement or expand, the European Union provisions on the free movement of Union citizens.

Since EU migration law cannot be of assistance, external relations law could well be a source for inspiration and direction. EEA nationals (including citizens of Norway, Iceland and Liechtenstein) and those enjoying derived rights of residence as family members of Union citizens residing on the territory of the host Member State are protected against expulsion. The Citizenship Directive removed the family members' dependency requirements in the case of death or departure of the Union citizen (Article 12 of Directive 2004/38), in the event of divorce, annulment of marriage or termination of the registered partnership (Article 13) or after five years of residence (Article 16). In addition to this privileged category of beneficiaries, beneficiaries of the agreements concluded by the Community and third countries, such as, for example, the 1963

\footnotetext{
${ }^{44}$ Compare here Article 28(1) of the Citizenship Directive.
} 
EEC-Turkey Association Agreement, ${ }^{45}$ its 1970 Protocol $^{46}$ and Decision 1/80 of the Association Council, ${ }^{47}$ enjoy security of residence. Indeed, according to Article 14(1) of Decision 1/80, the right of residence of a Turkish worker can be terminated on the grounds of public policy, public security or public health. The Court has held that the interpretation of Article 14(1) must mirror the interpretation given to these grounds as regards the rights of nationals of EU Member States and, in particular, the existence of a criminal conviction must constitute evidence of personal conduct posing a threat to the requirements of public policy and the threat must be genuine and sufficiently serious. ${ }^{48}$ Accordingly, expulsion cannot be ordered on general preventive grounds. ${ }^{49}$ The family members of Turkish workers, spouses and children, enjoy security of residence too. In fact, public policy, public security and public health considerations and absence from the host territory for a significant length of time without justification are the only two grounds on the basis of which they can be expelled. ${ }^{50}$

A lesser tier of protection is envisaged under the Maghreb Agreements (Tunisia, Morocco and Algeria) of 1976 which offer protection from discrimination in working conditions, social security and dismissal and subject the length of validity of the residence permit issued to a worker to public policy, public security and public health considerations. ${ }^{51}$ The same applies to the so-called Europe Agreements (the agreements concluded with Central and Eastern European countries, Baltic states and Slovenia) which provided for a right to free movement for selfemployment and protection from discrimination in working conditions. ${ }^{52}$ The Europe Agreements

\footnotetext{
${ }^{45}$ 64/732/EEC; Council Decision of 23 December 1963 on the Conclusion of the Agreement Establishing an Association between the EC and Turkey OJ 1964 217/3685.

${ }^{46}$ OJ 1973 C 113/2.

${ }^{47}$ Decision of 19 September 1980.

${ }^{48}$ Case C-340/97 Nazli v Stadt Nurnberg, [2000] ECR I-00957; Case C-467/02 Inan Cetinkaya v Land Baden-Wurttemberg [2004] ECR I-10895.

${ }^{49}$ Case C-349/06 Murat Polat v Stadt Russelsheim [2007] ECR I-08167.

${ }^{50}$ Case C-329/97 Sezgin Ergat v Stadt Ulm [2000] ECR I-1487.

${ }^{51}$ Case C-95/05 Mohamed Gattoussi v Stadt Russelsheim, Judgment of the Court of 14 December 2006; C416/96 El Yassini [1999] ECR I-1209.

52 See Kees Groenendijk, Elspeth Guild and Robin Barzilay, The Legal Status of Third Country Nationals who are Long-Term Residents in a Member State of the European Union, Centre for Migration Law,
} 
included a provision subjecting the exercise of the right of establishment to limitations imposed by the Member States on grounds of public policy, public security or public health. ${ }^{53}$ But no innovative ideas have been generated by the application and interpretation of these Agreements as regards the public policy and public security derogations. ${ }^{54}$ The interpretation given to these derogations is serialized in judgments and there is little or no departure from the established line of reasoning. What we are witnessing, therefore, is the contiguous effect of EU law and the CJEU's legitimate quest for coherence in the (strict) interpretation of the public policy, public security or public health derogations. After all, interpretative divergence in this area would not only contradict the Court's ruling in Nazli, ${ }^{55}$ but would also raise the spectre of affording the Member States different degrees of discretion to exclude individuals depending on their nationality, thus permitting discrimination on the ground of nationality.

\subsection{Public policy and public security in the case law of the CJEU}

Another source of inspiration might be the case law of the CJEU on the public policy and public security derogations across the four fundamental freedoms. Our survey of 233 judgments between the period of 1974 and 2011 (26 judgments regarding free movement of capital, 106 regarding free movement of goods, 30 regarding free movement of persons, and 71 regarding free

University of Nijmegen, the Netherlands, April 2000, and Council of Europe, Strasbourg, August 2000, available at <http://cmr.jur.ru.nl/cmr/docs/status.pdf>, last accessed 23 October 2012.

${ }^{53}$ For a comprehensive analysis, see Elspeth Guild, Nick Rollason and Rupert Copeman-Hill, A Guide to the Right of Establishment under the Europe Agreements (London: Baileys Shaw and Gillett in association with ILPA, 1996).

${ }^{54}$ Arguably, the same applies to provisions pertaining to EU external border law. The concepts of public policy, public security and national security entailed by the Schengen Implementing Convention (CISA) 1990, which forms part of the Schengen acquis which was integrated into the EU framework at Amsterdam (Council Decision 1999/435/EC of 20 May 1999, OJ L176, 10 July 1999) have not been defined, thereby inviting divergence in definitions provided for by national laws. Article 96 CISA provides pointers as to when an alien could be deemed to be a threat to public policy or public security for the purposes of entrance into the Schengen Information System.

${ }^{55}$ See $\mathrm{n} 47$ above. 
provision of services and freedom of establishment), ${ }^{56}$ reveals a prevalence in the use of derogation grounds in the field of free movement of goods, followed by its use in the field of free provision of services and freedom of establishment, and lastly in the field of free movement of persons and capital. ${ }^{57}$

Although all derogation grounds have been invoked throughout time to a greater or lesser extent, their discussion in CJEU judgments has indisputably increased in the 2000s and that is observable in relation to all derogation grounds: the survey has included 10 judgments from the 1970 s, 53 from the 1980s, and 56 from the 1990s, as opposed to 114 since 2000. The different relevance of each derogation ground in relation to the different freedoms is also striking: public health has clearly been more relevant in relation to free movement of goods (78 cases) and free provision of services/establishment (14 cases) than in relation to free movement of persons (3 cases) or free movement of capital (no case identified); public policy has been relevant in relation to free movement of goods, persons and provision of services/establishment (14, 18 and 20 cases respectively), but less relevant in relation to free movement of capital (4 cases); public security has been equally relevant with regard to all freedoms except free movement of persons $(6$ cases of free movement of goods, 5 cases of free movement of capital and 4 cases of free provision of services/establishment, but only 1 case of free movement of persons); finally, public interest has only been significant in relation to free movement of capital (17 cases) and free provision of

\footnotetext{
${ }^{56}$ This selection of case law includes decisions that have, one way or another, contributed to the definition of the scope of the derogation grounds under analysis; decisions that only tangentially refer to these notions, or that relate more to procedural than to substantive aspects of these notions, have not been included. All decisions have been categorized under one of the fundamental freedoms; when more than one freedom applied, the one most relevant on the facts and legal reasoning was chosen. All figures are presented here bearing in mind that they lack any degree of 'scientific certainty'; they are used with the mere purpose of identifying trends and highlighting possible commonalities and differences amongst the different derogation grounds and fundamental freedoms.

${ }^{57}$ The selection of case law analysed concentrates on the notions of public health, public policy and public security, but also covers, to a more limited extent, the notion of public interest. The latter is a very broad category and of limited relevance in the context of free movement of persons, but it often overlaps with the notions of the other derogation grounds in the case law of the CJEU. Bearing this in mind, we have analysed 95 judgments regarding public health, 56 regarding public policy, 16 regarding public security, 19 regarding all or a mix of derogation grounds, and 47 regarding public interest. When more than one ground applied and one of the grounds in question was particularly relevant, the most relevant ground invoked was afforded precedence for the purposes of this classification.
} 
services/establishment (27 cases), but not in relation to free movement of goods (1 case) or free movement of persons (2 cases). Public policy is, therefore, the ground most commonly invoked to derogate from free movement of persons (18 judgments relating to public policy, as opposed to only 3 relating to public health, 1 to public security, 2 to public interest, and 6 to all or a mix of derogation grounds). ${ }^{58}$ Public health and public security also appear to be the grounds invoked more successfully (29.5\% and $37.5 \%$ success rates respectively) in all four fields followed by the public policy and public interest derogation grounds (with success rates of $10.7 \%$ and $14.9 \%$ respectively). ${ }^{59}$ Public policy is the ground most commonly invoked to derogate from free movement of persons: it has been invoked in $24(80 \%)$ out of the 30 free movement of persons cases included in our survey, as either the only ground (in 18 cases) or a complementary one (in 6 cases).

The notion of public policy has perhaps been the most contentious amongst all derogation grounds. This owes much to the fact that there is not a 'uniform scale of values ${ }^{60}$ across all EU Member States, thereby leading the court to accept a certain margin of appreciation in determining the precise definitional content of public policy. Over time, it has brought within its

\footnotetext{
${ }^{58}$ It may be worthy of note that the Court shows reluctance to accept parties' invocation of derogation grounds. The number of 'exception allowed' cases amounts to 48 (20.6\%), of 'exception not allowed' to $158(67.8 \%)$, and of 'outcome dependent on national court' to $27(11.6 \%)$. The 'success rate' of derogation claims also varies considerably from freedom to freedom: it ranges from $7.7 \%, 10.0 \%$ and $16.9 \%$ in relation to free movement of capital, persons and services/establishment, respectively, to $29.2 \%$ in relation to the free movement of goods.

${ }^{59}$ The only exception to the success rate of the use of the public health derogation ground occurs in relation to free movement of persons, where the three cases included in this analysis did not lead to a successful claim: Cases 131/85 Emir Gül v Regierungspräsident Düsseldorf [1986] ECR 1573; C-111/91, Commission $v$ Luxembourg [1993] ECR I-817; and C-237/94 John O'Flynn v Adjudication Officer [1996] ECR I-2617. In Case 131/85 Emir Gül v Regierungspräsident Düsseldorf, the Court held that the public health exception was not intended 'to exclude the public health sector, as a sector of economic activity and from the point of view of access to employment, from the application of the principles of freedom of movement'. In Case C111/91 Commission v Luxembourg, the Court asserted that making 'the payment of childbirth and maternity allowances conditional upon requirements of prior residence on its territory' was discriminatory. Finally, in Case C-237/94 John O'Flynn v Adjudication Officer, the Court considered it to be a violation of the free movement of persons to make a 'grant of a payment to cover funeral expenses incurred by a migrant worker subject to the condition that burial or cremation take place within the territory of that Member State'.

${ }^{60}$ Cases 115 and 116/81 Rezguia Adoui v Belgian State and City of Liège; Dominique Cornuaille v Belgian State [1982] ECR 1665, paragraph 8; C-268/99 Aldona Malgorzata Jany and Others/Staatssecretaris van Justitie [2001] ECR I-8615, paragraph 60.
} 
ambit issues relating to combating organizations which are deemed to be non-conducive to the public good, ${ }^{61}$ limiting the free movement of individuals with a criminal record, ${ }^{62}$ preventing the export of coins no longer legal tender, ${ }^{63}$ avoiding the registration of stolen vehicles ${ }^{64}$ maintaining the non-commercial and pluralistic nature of a broadcasting system, ${ }^{65}$ supervising financial dealers, ${ }^{66}$ avoiding tax evasion/avoidance (and more generally guaranteeing the effectiveness of fiscal supervision),${ }^{67}$ combating the use of drugs, ${ }^{68}$ ensuring road safety,${ }^{69}$ combating gaming and betting, ${ }^{70}$ prohibiting games simulating acts of homicide, ${ }^{71}$ protecting young people, ${ }^{72}$ and more generally fighting criminal activities. ${ }^{73}$ Conversely, a range of other types of conduct have been excluded from the reach of the public policy derogation (at least on the precise facts of the case). These include the exercise of trade union rights, ${ }^{74}$ engaging in legal but 'morally suspect' activities, ${ }^{75}$ using a specific shape of wine bottle, ${ }^{76}$ protecting consumer rights, ${ }^{77}$ fixing a minimum price for fuel, ${ }^{78}$ refusing to accord sickness benefit to a director of a company formed in

\footnotetext{
${ }^{61}$ Case 41/74 Yvonne van Duyn v Home Office [1974] ECR 1337.

${ }^{62}$ Case 30/77 R v Pierre Bouchereau [1977] ECR 1999.

${ }^{63}$ Case 7/78 Thompson [1978] ECR 2247.

${ }^{64}$ Cases 154/85 Commission v Italy (Re Import of Foreign Motor Vehicles) [1985] ECR 1753; C-286/07 Commission v Luxembourg [2008] ECR I-63, paragraph 38.

${ }^{65}$ Case 352/85 Bond van Adverteerders and others $v$ the Netherlands [1988] ECR 2085.

${ }^{66}$ Cases C-163/94, C-165/94 and C-250/94 Criminal Proceedings against Lucas Emilio Sanz de Lera, Raimundo Díaz Jiménez and Figen Kapanoglu [1995] ECR I-4821, paragraph 26.

${ }^{67}$ Case C-28/95 A. Leur-Bloem v Inspecteur der Belastingdienst/Ondernemingen Amsterdam 2 [1997] ECR I-4161.

${ }^{68}$ Case C-348/96 Criminal Proceedings against Donatella Calfa [1999] ECR I-11, paragraph 22.

${ }^{69}$ Case C-451/99 Cura Anlagen GmbH v Auto Service Leasing GmbH (ASL) [2002] ECR I-3193.

${ }^{70}$ Case C-243/01 Piergiorgio Gambelli and Others [2003] ECR I-13031, paragraph 63.

71 Case C-36/02 Omega Spielhallen- und Automatenaufstellungs-GmbH v Oberbürgermeisterin der Bundesstadt Bonn [2004] ECR I-9609.

${ }^{72}$ Case C-244/06 Dynamic Medien Vertriebs GmbH v Avides Media AG [2008] ECR I-505.

${ }^{73}$ Case C-524/06 Heinz Huber v Bundesrepublik Deutschland [2008] ECR I-9705, paragraph 77.

${ }^{74}$ Case 36/75 Roland Rutili v Ministre de l'Intérieur [1975] ECR 1219.

${ }^{75}$ Cases 115 and 116/81 Rezguia Adoui v Belgian State and City of Liège; Dominique Cornuaille v Belgian State [1982] 3 CMLR 631.

${ }^{76}$ Case 16/83 Prantl [1984] ECR 1299.

${ }^{77}$ Case 177/83 Theodor Kohl KG v Ringelhan \& Rennett SA [1984] ECR 3651.

${ }^{78}$ Cases 231/83 Henri Cullet and Chambre syndicale des réparateurs automobiles et détaillants de produits pétroliers $v$ Centre Leclerc à Toulouse and Centre Leclerc à Saint-Orens-de-Gameville (29/01/1985); 34/84 Procureur de la République v Leclerc [1986] ECR 529; 114/84 and 115/84 Piszko v Leclerc et Carrefour Supermarché [1985] ECR 2961; 149/84 Procureur de la République v Binet [1985] ECR 2969; 201/84 Procureur de la République v Gontier [1985] ECR 2977; 202/84 Procureur de la République v Girault [1985] ECR 2985.
} 
accordance with the law of another Member State, ${ }^{79}$ imposing restrictions on the nationality of owners of companies responsible for the development of data-processing systems for public authorities, ${ }^{80}$ requiring prior registration with a social security scheme of the host State or registration with one particular social security scheme ${ }^{81}$ imposing a quota on moorings for nonresident owners, ${ }^{82}$ limiting the free movement of individuals not complying with legal formalities concerning the entry, movement and residence of aliens, ${ }^{83}$ allowing a non-member country to revoke, suspend or limit (air) traffic rights, ${ }^{84}$ and limiting the activity of non-national private security undertakings. ${ }^{85}$ And as already stated in section 2 above, any conduct triggering the public policy derogation must involve a 'genuine and sufficiently serious threat to the requirements of public policy affecting one of the fundamental interests of society', a phrase that has been frequently repeated by the Court since its first invocation in Bouchereau. ${ }^{86}$ In addition, the application of the public policy derogation does not depend on the imposition of penal sanctions ${ }^{87}$ and, as has been widely acknowledged, purely economic objectives are excluded from the scope of the public policy derogation ground. ${ }^{88}$

Besides the above mentioned general principles guiding the application of the public policy derogation, reflecting the 'strict interpretation' approach favoured by the Court, one cannot find insights relating to its definition which could migrate from the fields of free movement of

\footnotetext{
${ }^{79}$ Case 79/85 D. H. M. Segers v Bestuur van de Bedrijfsvereniging voor Bank-en Verzekeringswezen, Groothandel en Vrije Beroepen [1986] ECR 2375.

${ }^{80}$ Case 3/88 Commission v Italy [1989] ECR 4035.

${ }^{81}$ Case C-363/89 Danielle Roux v Belgian State [1991] ECR I-273, although the Court recognized 'compliance with social security provisions' as a possible public policy objective.

${ }^{82}$ Case C-224/97 Erich Ciola v Land Vorarlberg [1999] ECR I-2517.

${ }^{83}$ Cases 48/75 Procureur du Roi v Jean Noël Royer [1976] ECR 497; C-459/99 Mouvement contre le racisme, l'antisémitisme et la xénophobie ASBL (MRAX) v Belgium [2002] ECR I-6591; C-215/03 Salah Oulane v Minister voor Vreemdelingenzaken en Integratie [2005] ECR I-1215.

${ }^{84}$ Cases C-466/98 Commission v UK [2002] ECR I-9427; C-467/98 Commission v Denmark (Open Skies) [2002] ECR I-9519; C-476/98 Commission v Germany (Open Skies) [2002] ECR I-9855.

${ }^{85}$ Case C-465/05 Commission v Italy [2007] ECR I-11091.

${ }^{86}$ Case 30/77 R v Pierre Bouchereau [1977] ECR 1999, paragraph 35.

${ }^{87}$ Case 16/83 Prantl [1984] ECR 1299, paragraph 33.

${ }^{88}$ Cases C-17/92 Federación de Distribuidores Cinematográficos $v$ Estado Español et Unión de Productores de Cine y Televisión [1993] ECR I-2239, paragraph 21; C-243/01 Piergiorgio Gambelli and Others [2003] ECR I-13031, paragraph 26.
} 
goods, establishment and services and capital to the free movement of persons. Its ambit is varied and flexible. In addition, judgments have started to refer to an unclear notion of 'public order', seemingly meaning public policy, thereby intimating inconsistency either in the use of legal terminology or, more prosaically, in translation. ${ }^{89}$

\section{Why international migration law is more relevant than ever}

If neither EU migration and external relations laws nor the CJEU's case law can shed light on the meaning of the public policy and public security derogations, perhaps we should consider the extent to which international migration law could provide useful pointers as well as inspiration. The choice of international migration law as a possible point of departure has much to do with the fact that legal orders have become increasingly multilayered and interlaced. It is also due to the realization that norms in law, as indeed in other fields such as politics or economics, do not arise in a vacuum. Additionally, they have a capacity to permeate borders of all sorts; they readily migrate across spaces, legal orders and time precisely because they hold the promise of offsetting as well as solving social coordination problems and rights violations.

The need to protect migrant workers against arbitrary expulsion often ordered at the whim of the governmental authorities of the host state was felt acutely in the post-World War II era. In this respect, the protective provisions of Directive 64/221, which has been mentioned earlier, mirrored provisions entailed by international conventions. Admittedly, this is hardly surprising; most legal instruments are essentially mosaics entailing unique rearrangements of preexisting elements and legal fragments derived from various sources. More specifically, the 1949

\footnotetext{
${ }^{89}$ Cases C-465/05 Commission v Italy [2007] ECR I-11091; C-319/06 Commission v Luxembourg [2008] ECR I-4323, paragraph 29. The languages of these cases are, respectively, Italian and French, and the equivalent to 'public policy' in those languages is 'ordine pubblico' and 'ordre public', thus resembling much more 'public order' than 'public policy'.
} 
ILO Migration for Employment Convention (No 97), which entered into force in 1952, contained a number of protective measures. Recommendation R 086, which accompanied the 1949 Convention, envisaged the migrant workers' protection against removal from the host state for lack of sufficient means or the state of the employment market. ${ }^{90}$ It included the recommendation that 'in principle no migrant shall be removed who has been [in the host state] for more than five years' ${ }^{91}$ The increasing importance of the rights of non-citizen residents in host states was also highlighted by the initiatives taken under the aegis of the Council of Europe. The 1955 European Convention on Establishment ${ }^{92}$ undoubtedly contributed to changing assumptions about the allegedly unfettered sovereign prerogatives of states as regards the rights of 'aliens' in their jurisdiction. The obligation of states to facilitate the movement of nationals of other state parties was accompanied by the qualification that the activities of the persons concerned 'would [not] be contrary to ordre public, national security, public health or morality' (Article 1). The same applied with respect to expulsion. But what is worth highlighting here is the Convention's clear distinction between public order and national security - a distinction that is not reflected in the EU's rules on free movement. Having said this, however, we should also note that the European Convention on Establishment offered Member States a wide margin of discretion in interpreting these terms ${ }^{93}$ - certainly wider than the provisions of Directive 64/221 and the subsequent case law, since public order could include the exclusion of non-citizens on the ground of their political activity. But unlike the relevant EC rules prior to the adoption of the Citizenship Directive 2004/38, the 1955 Convention envisaged a system of graduated security of residence. Interestingly, the Convention provided that lawful residents for a period of at least two years could only be expelled on 'imperative considerations of national security' and they could challenge a decision and appeal against it before a competent authority of the host state (Article

\footnotetext{
${ }^{90}$ Recommendation 86 was adopted in Geneva on 8 June 1949.

${ }^{91}$ See Article 18(2).

92 1955, 529 UNTS 141, in force since 1965.

${ }^{93}$ See Sections I and III(a) of the Protocol to the Convention.
} 
3(2)). Legal residence of over ten years confined the expulsion to 'reasons of national security or for the commission of offences of a particularly serious nature against ordre public or morality' (Article 3(3)).

Subsequent conventions, such as the European Social Charter ${ }^{94}$ and the Revised European Social Charter ${ }^{95}$ include the right of migrant workers and their families to protection and assistance; Article 19(8) of the Revised European Social Charter states that lawful residents should not be expelled 'unless they endanger national security or offend against public interest or morality'. The European Convention on the Legal Status of Migrant Workers, ${ }^{96}$ on the other hand, reiterates the grounds of 'reasons of national security, public policy or morals' as exceptions to the rights of migrant workers to admission (Article 4(3)) and non-withdrawal of the residence permit (Article 9(5)(a)). To this regional regime of protection of migrant workers' security of residence one should add the Fourth Protocol to the ECHR which prohibits the collective expulsion of foreigners (Article 4).

In the early 1970s, the expulsion of the Asian population by Uganda highlighted the need for a more robust protection of migrant workers against arbitrary expulsions which had the effect of shattering people's lives overnight. The UN looked at the possibility of taking steps to protect the human rights of non-citizens and Baroness Elles produced a draft declaration on the human rights of individuals who are non-citizens of the country in which they live (the so-called Elles draft declaration) in $1974 .{ }^{97}$ The Elles draft declaration entailed the rights of non-citizens to 'freedom of movement and residence within the territory of the host country, subject, however, to such restrictions as are absolutely necessary for compelling reasons of public policy, public order, national security, or public health or morals' (Article 4[iii)]). And subsequently, the Draft Declaration on the Human Rights of Individuals Who are not Nationals of the Country in which

\footnotetext{
${ }^{94}$ CETS No 35, signed in Turin on 18 October 1961.

951996 CETS No 163.

${ }^{96}$ CETS No 093, adopted in Strasbourg in 1977.

97 See Richard Lillich, The Human Rights of Aliens in Contemporary International Law (Manchester: Manchester University Press, 1984), p. 51 et seq.
} 
They Live, adopted by the open-ended working group of the UN General Assembly, ${ }^{98}$ stated that 'the collective expulsion of aliens on the ground of criteria of race, religion, culture or any other discriminatory criterion is prohibited' (Article 7).

The privileging of the concrete lives of migrant workers over states' power of exclusion is also entailed by the 1990 International Convention on the Protection of the Rights of All Migrant Workers and Members of their Families which affirms the right of migrant workers to leave their home state without any illegitimate restrictions. Restrictions are only legitimate if they are provided by law, are necessary to protect national security, public order, public health or morals or the rights and freedoms of others and are consistent with the other rights recognized in the present part of the Convention Article 8(1). Migrants should not be subject to collective expulsions and expulsion decisions must comply with strict procedural safeguards (Article 22). The 1990 Convention also provides an additional tier of protection for documented workers: Article 56(2) states that '[e]xpulsion shall not be resorted to for the purpose of depriving a migrant worker or a member of his or her family of the rights arising out of the authorization of residence and the work permit', while the next paragraph of the same Article states that '[i]n considering whether to expel a migrant worker or a member of his or her family, account should be taken of humanitarian considerations and of the length of time that the person concerned has already resided in the State of employment'.99

More innovative and protective provisions have been brought forward in the new millennium. The Council of Europe Committee of Ministers Recommendations Rec No 15 (2000) on the security of residence of long-term migrants states that 'member states may provide that a long-term immigrant should not be expelled (...) after ten years of residence, except in the case of

\footnotetext{
${ }^{98}$ UN Doc. A/C.3/38/11 (1983).

${ }^{99}$ The Convention was adopted in 1990 by the UN General Assembly (Resolution 45/158 of 18 December 1990). No EU Member State has ratified it yet. For a discussion of the reasons, see Paul De Guchteneire, Antoine Pecoud and Ryszard Cholewinski (eds.), Migration and Human Rights: The United Nations Convention on Migrant Workers' Rights (Cambridge: UNESCO Publishing and Cambridge University Press, 2009).
} 
conviction for a criminal offence where sentenced to in excess of five years of imprisonment without suspension'; and '[a]fter twenty years of residence, a long-term immigrant should no longer be expellable' (4(b)). The subsequent paragraph also states that 'long-term immigrants born on the territory of the member state or admitted to the member state before the age of ten, who have been lawfully and habitually resident, should not be expellable once they have reached the age of eighteen. Long-term immigrants who are minors may in principle not be expelled' (4(c)). Arguably, such provisions could be readily utilized by the EU. Similarly, the Council of Europe Parliamentary Assembly Recommendation No 1504 (2001) on the non-expulsion of longterm immigrants invited national executives to: '[11]g. take the necessary steps to ensure that in the case of long-term migrants the sanction of expulsion is applied only to particularly serious offences affecting state security of which they have been found guilty; h. (...) guarantee that migrants who were born or raised in the host country and their under-age children cannot be expelled under any circumstances'. ${ }^{100}$

In light of the foregoing discussion, it is evident that international migration law contains important resources which could be utilized in a process of reforming Article 28 of the Citizenship Directive. Certainly, a case for greater isomorphism between EU law and international migration law could be defended and actualized by either confining Article 28(3) (i.e., the expulsion of EU citizens following ten years of residence in the host Member States and of minors) to national security grounds alone or even making long-term resident EU citizens and minors non-expellable, 'except if the expulsion is necessary for the best interests of the child', as stated in Article 28(3)(b). Certainly, for minors who have been born or raised in the country, expulsion constitutes such a seriously harmful act that it is impossible to justify from a normative point of view. Such a normative and legal 'spillover' would enhance the fundamental status of

\footnotetext{
${ }^{100}$ Available at <http://assembly.coe.int/Documents/AdoptedText/ta01/EREC1504.htm>, last accessed 23 October 2012.
} 
Union citizenship and make a concrete difference to the private and social lives ${ }^{101}$ of those beneficiaries of Directive 2004/38 who, for whatever reason, became transgressors of the law. After all, as Akerlof and Kranton have observed in another context, 'some of the most dramatic examples of regime change involve changes in norms regarding who is an insider and who is an outsider'. ${ }^{102}$

\section{Why national particularism is counterproductive: Proposals for law and policy reform}

The foregoing discussion has highlighted the impact of humanitarian considerations and norms on the progressive enhancement of the security of residence of migrant workers in the host country and defended the case for a greater parallelism between EU and international migration law. There has been a coherent underlying logic of circumscribing state discretion concerning the expulsion of long-term migrant residents and capturing in law newcomers' complex entanglement with the host society. Such entanglement with the host society makes them de facto members entitled to conduct their business and lives without the threat of forced removal or revocation of their residence statuses under 'flexible' definitions of public policy or public security threats. Ten years of residence, which is also the period required for eligibility for naturalization and acquisition of citizenship in several Member States, provides a reasonable cut-off point for the removal of long-term EU migrant offenders. ${ }^{103}$

\footnotetext{
${ }^{101}$ The ECtHR has acknowledged that the expulsion of settled migrants may interfere with the enjoyment of their right to private life which includes the social ties forged between settled migrants and the community in which they live, in addition to possible interferences with the right to respect for their family life under Article 8 ECHR; Mikulic v Croatia, no. 53176/99, paragraph 53.

${ }^{102}$ George A. Akerlof and Rachel E. Kranton, Identity Economics; How our Identities Shape our Work, Wages and Well-being (Princeton University Press, 2010), p. 125.

${ }^{103}$ Elspeth Berry defends an argument for the existence of a presumption against the deportation of 'virtual' nationals, that is, migrants who were born or raised in the host Member State. She argues that this would improve legal certainty and enhance non-discrimination; E. Berry, "The Deportation of "Virtual National" Offenders: The Impact of ECHR and EU Law' (2009) 23 Journal of Immigration, Asylum and Nationality Law, 11-23.
} 
The growing significance of European Union citizenship and its increasing alignment with fundamental rights also lends support to the above argument. Since EU citizenship is truly a fundamental status, then the continued removal of EU offenders following ten years of residence cannot be justified. Indeed, if EU citizens can be turned into expellable 'foreigners', notwithstanding their longstanding entanglement with, and participation in, the host society which EU law has facilitated through a variety of free movement provisions, including the permanent resident status established by Directive $2004 / 38,{ }^{104}$ then one could possibly argue that their membership had always been second class. They had never become 'one of us' or parts of the fabric of society in the host Member State.

There has also been a progressive realization in Europe of the need to provide unequivocal protection to migrant children born or raised in the host country and of bridging the dissonance between children's own perception of themselves as 'insiders' (as 'one of us') and governments' perception of them as continued 'outsiders' (as 'not one of us') even when they find themselves on the wrong side of the law. Migrant children who have spent all or most of their childhood in a society, been brought up and educated in line with its guiding principles and frameworks and have their home there should not be treated as 'non-belongers' and undeserving residents if they become law-breakers. After all, there is hardly any evidence to suggest that lawbreaking is either a by-product of their 'alien' nationality or an act intimately associated with a certain nationality status. To pretend that there is would be tantamount to concealing its social dimensions, notwithstanding its complexity and varied manifestations, and to uncritically tolerate nationalistic proclamations about 'dangerous aliens' contaminating the alleged purity of the national society or discursive narratives about undeserving EU citizens who violated a country's hospitality rules and therefore must be expelled. As Judge Martens has observed in Beljoudi,

\footnotetext{
${ }^{104}$ Compare here Recital 18 of the Citizenship Directive which states that 'in order to be a genuine vehicle for integration into the society of the host Member State in which the Union citizen resides, the right to permanent residence, once obtained, should not be subject to any conditions'.
} 
'mere nationality does not constitute an objective and reasonable justification for the existence of a difference as regards expulsion'. ${ }^{105}$

Children who have spent all or most of their childhood in a certain country are so intimately connected with their social surroundings that their removal does not only shatter the social world they legitimately call their own but also their personal identities which have been formed within this social world. And in the same way that it would be regarded as both disproportionate and deeply troubling if a state decided to revoke a person's citizenship status because he/she committed a criminal offence, it should be considered to be equally disproportionate and troubling if migrant children's membership status were automatically erased if they committed the same offence. Punishment ${ }^{106}$ in both cases cannot, and should not, result in erasing their societal membership status and crushing their lives. In this respect, there exist powerful reasons for making the treatment of national minors and migrant minors assimilable and for questioning the assumption that there exists an incommensurability between law-compliance and the possession of a certain nationality.

\footnotetext{
${ }^{105}$ Concurring Opinion in Beljoudi v France, 234 European Court of Human Rights (ser. A) (1992).

${ }^{106}$ It is noteworthy here that the ECtHR has ruled that expulsion following criminal conviction does not constitute double punishment and that states have the power to expel regardless of whether the alien entered the country as an adult or at a young age or was perhaps born there; Uner $v$ the Netherlands Judgment of 18 October 2006, no 46410/99 ECHR 2006-XII. Uner was a Turkish migrant resident in the Netherlands since the age of 12 and, as settled and married with a Dutch national and a father of children, had a strong entitlement to reside in the Netherlands. But although 'he had integrated to society to the extent that he did not think of himself as a stranger', the ECtHR relied on the margin of appreciation enjoyed by states in assessing migration cases and asserted the differential position of nationals from nonnational residents belonging to the category of second generation or long-term immigrants in terms of rights of residence. However, it also outlined a number of considerations that should be taken into account in such migration decisions, such as the age of children of the marriage, the difficulties that either the spouse or the children may experience in the country to which the individual is to be expelled, as well as the solidity of social, cultural and family ties with the host country and the country of destination (paragraphs 57-58). See also Baghli v France, Judgment of 30 November 1999, no 34374/97 ECHR 1999VIII. In Omojudi $v$ United Kingdom, Judgment of 24 November 2009, no 1820/08, the ECtHR acknowledged that the totality of social ties between settled migrants and the community should be taken into account. It ruled that the deportation of a Nigerian national who had lived in the UK for 24 years interfered with his family life as well as his private life. But compare Maslov v Austria (2008), Judgment of 23 June 2008, no 1638/03; Bousarra v France, Judgment of 23 September 2010, no 25672/07; A. W. Khan v UK, Judgment of 12 January 2010, no 47486/06; in these cases the ECtHR did find a violation of Article 8 ECHR.
} 
It is true that EU law has thus far provided the most comprehensive system of ensuring security of residence for EU citizens, but as we saw in section 2, the correct implementation of Directive $2004 / 38$ remains a challenge ${ }^{107}$ and there is a need for improving its relevant provisions. International migration law can furnish ideas and insights for reform which are consonant with European Union law norms and capable of enhancing the latter's integrity as well as effectiveness in national arenas. In this respect, a revised Article 28(3) of Directive 2004/38 should either confine an expulsion decision against long-term resident EU citizens and minor EU citizens to imperative grounds of national security, 'along the lines of preserving the integrity of the territory of a Member State and its institutions, ${ }^{108}$ or those categories of citizens should not be expellable at all. Additionally, the inclusion of a fourth paragraph in Article 28 of Directive 2004/38 stating that 'collective expulsions, including expulsions of ethnic groups, are prohibited' is necessary in view of the expulsion of Roma in Italy and France.

The alternative is, of course, national divergence. And national divergence may be consonant with the doctrine of statist positivism, but it also results in creating both holes in the system of protection of EU citizens afforded by EU law and layers of injustice. There may well exist as many as 27 differing legal provisions concerning the definitions of public policy and public security in the EU owing to the wide discretion enjoyed by the Member States. The ECJ has acknowledged that the term 'public policy' is a national law concept subject to national interpretation. ${ }^{109}$ As mentioned in Gaydarov, 'while Member States essentially retain the freedom to determine the requirements of public policy and public security in accordance with their national needs, which can vary from one Member State to another and from one era to another, the fact still remains that, in the European Union context and particularly as a justification for a derogation from the fundamental principle of free movement of persons, those requirements must be interpreted strictly, so that their scope cannot be determined unilaterally by each Member State

\footnotetext{
${ }^{107}$ On this see the Commission's Communication, $\operatorname{COM}(2009) 313$ final.

${ }^{108}$ Ibid., at p. 10.

${ }^{109}$ Case C-268/99 Aldona Malgorzat Jany v Ministre de l'Interieur [1975] ECR I-8615, paragraph 60.
} 
without any control by the institutions of the European Union'. ${ }^{110}$ Further, the progressive development of Union citizenship and its constitutional metamorphosis into a fundamental status ${ }^{111}$ challenges the maintenance of the status quo. EU citizenship, which has been developed mainly outside the domain of state sovereignty, cannot be compromised by acts designed to preserve state sovereignty and nationalistic understandings of societal membership and belonging.

In addition, although all Member States recognize that long-term residents and certain groups ought to have a more secure residence status and stronger procedural guarantees against their expulsion from the host state, their respective provisions differ as regards their personal scope, the stipulated duration of residence and the degree of reception of ECtHR case law. As such, they could hardly provide a guide as to how the terms 'public policy' or 'public security' need to be interpreted, what the meaning of 'imperative grounds of public security' is, and what kind of protection should be offered to minors who have few or no links with the country which features in their passport or their parents' passport. For instance, while in Germany the length of residence or residence status or birth there as second or third generation offspring would not guarantee security of residence, in Belgium settled migrants can only be removed if they have gravely harmed public order and security. ${ }^{112}$ Additionally, the expulsion of those born in Belgium

\footnotetext{
${ }^{110}$ Case C-430/10 Gaydarov, paragraph 32, n 2 above.

${ }^{111}$ D. Kostakopoulou, 'The European Court of Justice, Member State Autonomy and European Union Citizenship: Conjunctions and Disjunctions', in B. de Witte and Hans-W. Micklitz (eds.), The European Court of Justice and the Autonomy of the Member States (Leiden: Intersentia, 2012); 'Ideas, Norms and European Citizenship: Explaining Institutional Change', Modern Law Review, Vol. 65 (2), 2005, 233-267. On the post-Rottmann developments, see Koen Lenaerts, "CCivis Europeus Sum": From the Cross-Border Link to the Status of Citizens of the Union', Online Journal on Free Movement of Workers within the European Union, December 2011, No. 3, European Commission; Publications Office of the EU, Luxembourg, <www.ec.europa.eu/social/BlobServlet?docId=7281\&langId=en>, last accessed 23 October 2012; Dimitry Kochenov, 'A Real European Citizenship: The Court of Justice Opening a New Chapter in the Development of the Union in Europe', Columbia Journal of European Law, Vol. 18(1), 2012, 55-109; 'New European Citizenship: A Move Beyond the Market Bias', in R. Bellamy and U.Staiger (eds.), EU Citizenship and the Market (London: University College London, 2011).

${ }^{112}$ Article 20 (Belgian) Immigration Law.
} 
or who have lived there from the age of 12 onwards is prohibited. ${ }^{113}$ This means that the second or third generation migrant children are entitled to full security of residence even though they may have not acquired Belgian nationality. Besides Belgium, Austria, France, Hungary, Portugal and Sweden also prohibit the deportation of second generation migrants on account of a criminal record. In these states, migrants who arrived in the host country during childhood are also protected, notwithstanding the existence of divergence regarding the precise age of newcomers. In contrast, according to the German Residence Act (AufenthG), ${ }^{114}$ had the same migrant child been born in Germany, he/she would not be in a position to enjoy security of residence even if the offence committed there were relatively minor.

In the light of the foregoing discussion it may be concluded that national regulatory autonomy in this field leads to the creation of several 'tiers' of protection of EU citizens and to unpredictability, thereby rendering the EU citizenship status a weak and feeble overlay or, perhaps, even a fiction. The task is to maintain the gravity of liberal norms, the importance of the fundamental status of EU citizenship and the new and broader social space it has created. We need to go forward, not backward. This can only be done if between the fictional and the real, between 'foreignness' and EU citizenship, between the state and the individual, between sovereignty and security, space emerges for critical reflection and for institutional change. For the continued expulsion of long-term resident EU citizens and minors should not be viewed as a mere manifestation of Member States' prerogatives in the fields of migration and security; it tests the meaning and significance of European Union citizenship and impacts on the particularization of the ideals underpinning both liberalism and European integration. ${ }^{115}$ And adherence to these

\footnotetext{
${ }^{113}$ Compare here Lord Justice Sedley's remark in SSHD v HK (Turkey): 'The number of years a potential deportee has been here is always likely to be relevant; but what is likely to be more relevant is the age at which those years began to run. Fifteen years spent here as an adult are not the same as fifteen years spent here as a child. The difference between the two may amount to the difference between enforced return and exile.' ([2010] EWCA Civ 583, paragraph 35).

${ }^{114}$ Residence Act of 30 July 2004; Aufenthaltsgesetz.

${ }^{115}$ Compare here AG Jacobs' statement of 'civis europaeus sum' in Case C-168/91 Konstantinidis [1993] ECR I-1198, point 46.
} 
ideals, at the very minimum, requires that no interpretation of the Citizenship Directive should be arbitrary, even more so when it implies harm to human beings and injustice. 